\section{Sosialisasi Pengalokasian Dana \\ Tepat Guna Dan Sasaran Dalam Kehidupan Ummat Di SMA Tri Dharma Palembang}

\author{
Meriyati, Amir Salim \\ Program Studi Perbankan Syariah STEBIS IGM Palembang \\ Program Studi Ekonomi Syariah STEBIS IGM Palembang \\ Email : meri@ stebisigm.ac.id, amirsalim@stebisigm.ac.id
}

\begin{abstract}
The second bank activity after collecting funds from the wider community in the form of deposits, savings and time deposits is to channel these funds back to the people who need them. The activity of channeling funds is also known as fund allocation. The allocation of funds can be realized in the form of loans or better known as loans to conventional banks and financing to sharia-based banks. Both types of distribution of funds have advantages and disadvantages of each. Giving credit or financing can be said to be economic stability because with the credit given will increase the amount of goods needed by the community. Then credit can also help in exporting domestic goods abroad so as to increase the country's foreign exchange. To increase the excitement of trying, for the recipient of the credit will certainly be able to increase the excitement of doing business, especially for the customer who is mediocre capital. To increase income distribution. The more credit / financing distributed, the better, especially in terms of increasing income. However, these two types of products both credit and financing will be the best solution for the Ummah if the allocation of these funds is used appropriately and with the right target.
\end{abstract}

Keywords : Fund Allocation, SMA Tri Dharma

\begin{abstract}
Abstrak
Kegiatan bank yang kedua setelah menghimpun dana dari masyarakat luas dalam bentuk simpanan giro, tabungan dan deposito adalah menyalurkan kembali dana tersebut kepada masyarakat yang membutuhkannya. Kegiatan penyaluran dana ini dikenal juga dengan istilah alokasi dana. Pengalokasian dana dapat diwujudkan dalam bentuk pinjaman atau lebih dikenal dengan kredit pada bank konvensional dan pembiayaan pada bank berbasis syariah. Kedua jenis penyaluran dana ini memiliki keunggulan dan kekurangan masingmasing. Dengan memberikan kredit ataupun pembiayaan dapat dikatakan sebagai stabilitas ekonomi karena dengan adanya kredit yang diberikan akan menambah jumlah barang yang diperlukan oleh masyarakat. Kemudian dapat pula kredit membantu dalam mengekspor barang dalam negeri ke luar negeri sehingga meningkatkan devisa Negara. Untuk meningkatkan kegairahan berusaha, bagi si penerima kredit tentu akan dapat meningkatkan kegairahan berusaha, apalagi bagi si nasabah yang memang modalnya paspasan. Untuk meningkatkan pemerataan pendapatan. Semakin banyak kredit/ pembiayaan yang disalurkan, akan semakin baik, terutama dalam hal meningkatkan pendapatan. Namun, kedua jenis produk ini baik kredit maupun pembiayaan akan menjadi solusi terbaik bagi ummat jika pengalokasian dana tersebut di gunakan dengan tepat guna dan sasaran yang tepat.
\end{abstract}

Kata Kunci: Pengalokasian Dana, SMA Tri Dharma 


\section{Pendahuluan}

Dalam kehidupan ummat perekonomian sangatlah mewarnai kehidupan sehari-hari, keuntungan utama bisnis perbankan adalah selisih antara bunga dari sumber-sumber dana dengan bunga yang diterima dari alokasi dana tertentu. Sedangkan menurut Kasmir (2014: 58). sumber-sumber dana bank adalah usaha bank dalam menghimpun dana untuk membiayai operasinya. Oleh karena itu, baik faktor-faktor sumber dana maupun alokasi dana memegang peranan yang sama pentingnya di dunia perbankan. Penentuan bunga sumber dana akan sangat berpengaruh terhadap bunga alokasi dana yang akan dibebankan. Pembahasan dalam bab ini hanya dikhususkan kepada alokasi dana yang paling utama dan puling penting bagi kegiatan perbankan.

Kegiatan alokasi dana yang terpenting tersebut adalah alokasi dana dalam bentuk pinjaman atau lebih dikenal dengan kredit bagi bank berdasarkan prinsip konvensional dan pembiayaan bagi bank yang berdasarkan prinsip syariah. Bank harus memperhatikan prinsip-prinsip pemberian kredit yangsehat. Adapun yang merupakanprinsip-prinsip perkreditan adalah: 1 Prinsip Kehati-hatian, 2. Prinsip Kepercayaan, 3. Prinsip Sinkronisasi, 4. Prinsip Kesamaan Valuta, 5. Prinsip Perbandingan antara Pinjamandengan Modal.

Banyak masyarakat yang belum paham pengalokasian dana tepat guna dan sasaran dalam kehidupan ummat di SMA Tri Dharma Palembang, perbedaan kredit dan pembiayaan syariah, Pengertian Pengalokasian Dana, Pengertian Kredit dan Pembiayaan, Penyaluran Dana Pembiayaann Kepada Masyarakat, prinsipprinsip Pemberian Kredit, Aspek-aspek dalam Penilaian, Prosedur dalam Pemberian Kredit. Kami selaku dosen pada Sekolah Tinggi Ekonomi dan Bisnis Syariah mensosialikan tentang pengalokasian dana tepat guna dan sasaran dalam kehidupan ummat.

Target kami adalah siswa-siswi SMA, MA dan Pondok Pesantren yang ada di wilayah Palembang dan sekitarnya. Kegiatan ini di lakukan agar para siswa dan guru lebih mengenal tentang pengalokasian dana tepat guna dan sasaran dalam kehidupan terutama umat muslim yang ingin menyimpan uangnya atau mungkin menginvestasikan uang yang mereka miliki pada lembaga keuangan yang berbasis syariah. Pada kesempatan kali ini kami mensosialisasikan kegiatan ini di SMA Tri Dharma Palembang. kamipilih sebagai tempat pengabdian pada masyarakat karena murid di SMA ini cukup banyak dan SMA ini merupakan salah satu SMA yang mayoritas guru dan muridnya menganut agama Islam.

\section{Metode Pengabdian}

Pelaksanaan kegiatan sosialisasi ini kami lakukan dengan cara yaitu dengan metode presentasi, pembagian brosur dan pembukaan beberapa sesi tanya jawab dengan para guru maupun peserta didik. Ada beberapa tahapan yang kami yang kami lakukan yaitu: (1) Tahap persiapan; (2) Tahap pelaksanaan; (3) Tahap akhir.

1. Tahap Persiapan

Tahap persiapan ini dilakukan untuk mengetahui sejauh mana pengetahuan para guru dan murid di SMA Tri Dharma Palembang tentang Pengalokasian Dana Tepat Guna Dan Sasaran Dalam Kehidupan Ummat. Selain itu juga untuk mengetahui berapa banyak siswa/siswi yang akan ikut dalam sosialisasi ini sehingga pemateri akan tahu berapa banyak persiapan fotokopi materi yang 
diperlukan, snack, dan lain sebagainya. Adapun tahapan persiapan tersebut antara lain :

a. Pengantaran surat permohonan pengabdian ke kepala Sekolah SMA Tri Dharma Palembang.

b. Setelah mendapat balasan dari kepala Sekolah, kami melakukan kunjungan ke SMA Tri Dharma untuk mengetahui kapan tepatnya sosialisasi ini dapat kami laksanakan.

c. Membuat Materi yang akan di sampaikan saat sosilasisasi dilakukan

d. Membuat dan merincikan apa-apa saja yang dibutuhkan (seperti : berapa banyak soevenir akan dibawa, berapa snack yang dibutuhkan, dll).

\section{Tahap Pelaksanaan}

Sosialisasi ini dilaksanakan dalam jangka waktu 2 (dua) hari. Pada hari pertama yang disampaikan oleh pemateri pertama yaitu : Ibu Meriyati, M.H.I, sedangkan pada hari kedua disampaikan oleh pemateri kedua yaitu Bapak Amir Salim, S.E.I.,M.E.

Materi hari pertama : Pengertian Pengalokasian Dana, Pengertian Kredit dan Pembiayaan, Penyaluran Dana Pembiayaann Kepada Masyarakat, Unsur-unsur Kredit.

Materi hari kedua : Tujuan dan Fungsi Kredit, Jenis-jenis Kredit, Jaminan Kredit, Prinsip-prinsip Pemberian Kredit, Aspek-aspek dalam Penilaian, Prosedur dalam Pemberian Kredit.

3. Tahap Akhir

Setelah tahap pelaksanaan dilakukan maka tahap selanjutnya merupakan tahap akhir. Tahap akhir meliputi beberapa kegiatan yaitu :

a. Melakukan evaluasi hasil kegiatan dengan cara melihat hasil kuisioner yang sudah diberikan kepada siswa-siswi yang mengikuti kegiatan sosialisasi.

b. Jika hasil kuisioner belum memuaskan seperti yang diharapkan maka mencatat kebutuhan yang diperlukan agar kegiatan sosialisasi berikutnya akan lebih baik.

c. Membuat laporan hasil kegiatan sosialisasi

d. Mengumpulkan laporan yang telah dibuat.

\section{Hasil Dan Pembahasan}

Pengalokasian dana dapat pula dilakukan dengan membelikan berbagai aset yang dianggap menguntungkan bank. Arti lain dari alokasi dana adalah menjual kembali dana yang diperoleh dari penghimpunan dana dalam bentuk simpanan. Penjualan dana ini tidak lain agar perbankan dapat memperoleh keuntungan seoptimal mungkin, dalam mengalokasikan dananya pihak perbankan harus dapat memilih dari berbagai alternatif yang ada. Kegiatan alokasi dana yang terpenting tersebut adalah alokasi dana dalam bentuk pinjaman atau lebih dikenal dengan kredit bagi bank berdasarkan prinsip konvensional dan pembiayaan bagi bank yang berdasarkan prinsip syariah. (Nasution, 1990). Bank harus memperhatikan prinsip-prinsip pemberian kredit yangsehat. Adapun yang merupakanprinsipprinsip perkreditan adalah: 1 Prinsip Kehati-hatian, 2. Prinsip Kepercayaan, 3. Prinsip Sinkronisasi, 4. Prinsip Kesamaan Valuta, 5. Prinsip Perbandingan antara Pinjamandengan Modal. (Fuady, 2002: 11). 


\section{Pengertian Kredit dan Pembiayaan}

Menurut Undang-Undang Perbankan Nomor 10 Tahun 1998: "Kredit adalah penyediaan uang atau tagihan yang dapat dipersamakan dengan itu, berdasarkan persetujuan atau kesepakatan pinjarn meminjam antara bank dengan pihak lain yang mewajibkan pihak peminjam melunasi utangnya setelah jangka waktu tertentu dengan pemberian bunga. (Siamat, 2001:165). Sedangkan pengertian pembiayaan adalah penyediaan uang atau tagihan yang dapat dipersamakan dengan itu, berdasarkan persetujuan atau kesepakatan antara bank dengan pihak lain yang mewajibkan pihak yang dibiayai untuk mengembalikan uang atau tagihan tersebut setelah jangka waktu tertentu dengan imbalan atau bagi hasil". (ttps://www.jogloabang.com/pustaka/uu-10-1998-perubahan-uu-7-1992perbankan)

Dari pengertian di atas dapatlah dijelaskan bahwa kredit atau pembiayaan dapat berupa uang atau tagihan yang nilainya diukur dengan uang, misalnya bank membiayai kredit untuk pembelian rumah atau mobil. Kemudian adanya kesepakatan antara bank (kreditor) dengan nasabah penerima kredit (debitur), bahwa mereka sepakat sesuai dengan. perjanjian yang telah dibuatnya. Dalam perjanjian kredit tercakup hak dan kewajihan masing-masing pihak, termasuk jangka waktu serta bunga yang ditetapkan bersama.

Demikian pula dengan masalah sangsi apabila si debitur ingkar janji terhadap perjanjian yang telah dibuat bersama. Yang menjadi perbedaan antara kredit yang diberikan oleh bank berdasarkan konvensional dengan pembiayaan yang diberikan oleh bank berdasarkan prinsip syariah adalah terletak pada keuntungan yang diharapkan. Bagi bank berdasarkan prinsip konvensional keuntungan yang diperoleh melalui bunga sedangkan bagi bank yang berdasarkan prinsip bagi hasil berupa imbalan atau bagi hasil. (Suharto, 1998).

Dalam artian luas kredit diartikan sebagai kepercayaan. Begitu pula dalam bahasa latin kredit berartikan "creder" artinya percaya. Maksud dari percaya bagi si pemberi kredit adalah penerima kredit yang yang disalurkannya pasti akan dikembalikan sesuai perjanjian. Sedangkan bagi si penerima kredit merupakan penerimaan kepercayaan sehingga mempunyai kewajiban untuk membayar sesuai jangka waktu. Sebelum kredit diberikan, untuk meyakinkan bank bahwa nasabah benar-benar dapat dipercaya, maka bank terlebih dulu mengadakan analisis kredit. Analisis kredit mencakup latar belakang nasabah atau perusahaan, prospek usahanya, jaminan yang diberikan serta faktor- faktor lainnya. Tujuan analisis ini adalah agar bank yakin bahwa kredit yang diberikan benar-benar aman. (Suharto, 1998).

\section{Penyaluran Dana Pembiayaann Kepada Masyarakat}

Pada penyaluran dana kepada masyarakat, sebagian besar pembiayaan Bank Islam disalurkan dalam bentuk barang atau jasa yang dibelikan bank Islam untuk nasabahnya. Dengan demikian, pembiayaan hanya diberikan apabila barang/jasanya telah ada terlebih dahulu. Dengan metode ada barang dulu, baru ada uang maka masyarakat dipacu untuk memproduksi barang/jasa atau mengadakan barang/jasa. Barang yang dibeli- diadakan menjadi jaminan (colaltera) utang. Secara garis besar, hubungan ekonomi berdasarkan syariah Islam tersebut ditentukan oleh hubungan aqad yang terdiri dari aqad. Bersumber dari kelima konsep dasar inilah dapat ditemukan produk - produk lembaga 
keuangan Bank Syariah dan lembaga keuangan bukan Bank Syariah untuk dioperasionalkan.

Kelima konsep tersebut adalah : (1) sistem simpanan, prinsip Simpanan Murni (al-wadiah) Prinsip simpanan murni merupakan fasilitas yang diberikan oleh Bank Islam untuk memberikan kesempatan kepada pihak yang kelebihan dana untuk menyimpan dananya dalam bentuk al -wadiah. Fasilitas al -wadiah biasa diberikan untuk tujuan investasi guna mendapatkan keuntungan seperti halnya tabungan dan deposito. Pada akad wadiah bank dimungkinkan memberikan bonus kepada pemilik harta sebagai sebuah insentif selama tidak diperjanjikan dalam akad pembukaan rekening. (Karim. 2006: 298). Dalam dunia perbankan konvensional al -wadiah identik dengan giro. (2) bagi hasil, bagi Hasil (syirkah) Sistem ini adalah suatu sistem yang meliputi tata cara pembagian hasil usaha antara penyedia dana dengan pengelola dana. Pembagian hasil usaha ini dapat terjadi antara Bank dengan penyimpanan dana, maupun antara Bank dengan nasabah penerima dana. (3) margin keuntungan, (4) sewa, (5) fee (jasa). Bentuk produk yang berdasarkan prinsip adalah mudharabah dan musyarakah. Lebih jauh prinsip mudharabah. (Muhammad, 2000).

\section{Unsur-unsur Kredit}

Dari penjelasan di atas dapatlah diuraikan hal-hal apa saja yang terkandung dalam pemberian suatu fasilitas kredit. Atau dengan kata lain pengertian kata kredit jika dilihat secara utuh mengandung makna apa saja sehingga jika kita bicara kredit, maka termasuk membicarakar. unsur-unsur yang terkandung di dalamnya. (Suharto, 1998). Adapun unsur-unsur yang terkandung dalam pemberian suatu fasilitas kredit adalah sebagai berikut:

1. Kepercayaan, yaitu suatu keyakinan pemberi kredit bahwa kredit yang diberikan (berupa uang, barang atau jasa) akan benarbenar diterima kem- bali di masa tertentu di masa datang. Kepercayaan ini diberikan oleh bank, di mana sebelumnya sudah dilakukan peneiitian pe- nyelidikan tentang nasabah baik secara interen maupun eksteren. Peneiitian dan penyelidikan tentang kondisi masa lalu dan seka- rang terhadap nasabah pemohon kredit.

2. Kesepakatan, unsur percaya di dalam kredit juga mengandung unsur kesepakatan antara si pemberi kredit dengan si penerirna kredit. Kesepakatan ini dituangkan dalam suatu perjanjian di mana masing-masing pihak menandatangani hak dan kewajibannya masing-masing. Jangka waktu, setiap kredit yang diberikan memiliki jangka waktu tertentu, jangka waktu ini mencakup masa pengembalian kredit yang telah disepakati. Jangka waktu tersebut bisa berbentuk jangka pendek, jangka menengah atau jangka panjang.

3. Risiko, suatu tenggang waktu pengembalian akan menyebabkan suatu risiko tidak tertagihnya/macet pemberian kredit. Semakin panjang suatu kredit semakin besar risikonya demikian pula sebaliknya. Risiko ini menjadi tanggungan bank, baik risiko yang disengaja oleh nasabah yang lalai, maupun oleh risiko yang tidak sengaja. Misalnya terjadi bencana alam atau bangkrutnya usaha nasabah tanpa ada unsur kesengajaan lainnya. Balas jasa, merupakan keuntungan atas pemberian suatu kredit atau jasa tersebut yang kita kenal dengan nama bunga. Balas jasa dalam bentuk bunga dan biaya 
administrasi kredit ini merupakan keuntungan bank. Sedangkan bagi bank yang berdasarkan prinsip syariah balas jasanya ditentukan dengan bagi hasil.

\section{Tujuan dan Fungsi Kredit}

Pemberian suatu fasilitas kredit mempunyai tujuan tertentu. Tujuan pemberian kredit tersebut tidak akan terlepas dari misi bank tersebut didirikan. Adapun tujuan utama pemberian suatu kredit adalah sebagai berikut: 1. Mencari keuntungan, yaitu bertujuan untuk memperoleh hasil dari pemberian kredit tersebut. Hasil tersebut terutama dalam bentuk bunga yang diterima oleh bank sebagai balas jasa dan biaya administrasi kredit yang dibebankan kepada nasabah. Keuntungan ini penting untuk kelangsungan hidup bank. Jika bank yang terusmenerus menderita kerugian, maka besar kemungkinan bank tersebut akan dilikuidasi (dibubarkan).

Membantu usaha nasabah, tujuan lainnya adalah untuk membantu usaha nasabah yang memerlukan dana, baik dana investasi maupun dana untuk modal kerja. Dengan dana tersebut, maka pihak debitur akan dapat mengembangkan dan memperluaskan usahanya. Membantu pemerintah, bagi pemerintah semakin banyak kredit yang disalurkan oleh pihak perbankan, maka semakin baik, mengingat semakin banyak kredit berarti adanya peningkatan pembangunan di berbagai sektor.

Keuntungan bagi pemerintah dengan menyebarnya pemberian kredit adalah sebagai berikut: a. Penerimaan pajak, dari keuntungan yang diperoleh nasabah dan bank, b. Membuka kesempatan kerja, dalam hal ini untuk kridit pembangunan usaha baru atau perluasan usaha akan membutuhkan tenaga kerja baru sehingga dapat menyedot tenaga kerja yang masih menganggur, c. Meningkatkan jumlah barang dan jasa, jelas sekali bahwa sebagian besar kredit yang disalurkan akan dapat meningkatkan jumlah barang dan jasa yang beredar di masyarakat, $d$. Menghemat devisa negara, terutama untuk produk-produk yang sebelumnya diimpor dan apabila sudah dapat diproduksi di dalam negeri dengan fasilitas kredit yang ada jelas akan dapat menghemat devisa Negara, e. Meningkatkan devisa negara, apabila produk dari kredit yang dibiayai untuk keperluan ekspor. (Suharto, 1998)

Kemudian di samping tujuan di atas suatu fasilitas kredit memiliki fungsi sebagai berikut.. Untuk meningkatkan daya guna uang, dengan adanya kredit dapat meningkatkan daya guna uang maksudnya jika uang hanya disimpan saja tidak akan menghasilkan sesuatu yang berguna. Dengan diberikannya kredit uang tersebut menjadi berguna untuk menghasilkan barang atau jasa oleh si penerima kredit. Untuk meningkatkan peredaran dan lalu lintas uang, dalam hal ini uang yang diberikan atau disalurkan akan beredar dari satu wilayah ke wilayah lainnya sehingga suatu daerah yang kekurangan uang dengan memperoleh kredit maka daerah tersebut akan memperoleh tambahan uang dari daerah lainnya, Untuk meningkatkan daya guna barang, kredit yang diberikan oleh bank akan dapat digunakan oleh si debi- tur untuk mengolah barang yang tidak berguna menjadi berguna atau bermanfaat. Meningkatkan peredaran barang, kredit dapat pula menambah atau memperlancar arus barang dari yang beredar dari satu wilayah ke wilayah lainnya sehingga jumlah barang yang beredar dari satu wilayah ke wilayah lainnya bertambah atau kredit dapat pula meningkatkan jumlah barang yang beredar. (Djumhana, 2003. 372) 
Jika sebuah kredit diberikan untuk membangun pabrik, maka pabrik tersebut tentu membutuhkan tenaga kerja sehingga dapat pula mengurangi pengangguran. Di samping itu, bagi masyarakat sekitar pabrik juga akan dapat meningkatkan pendapatannya seperti membuka warung atau menyewa rumah kontrakan atau jasa lainnya. Untuk meningkatkan hubungan internasional, dalam hal pinjaman internasional akan dapat meningkatkan saling membutuhkan antara si penerima kredit dengan si pemberi kredit. Pemberian kredit oleh negara lain akan meningkatkan kerja sama dalam bidang lainnya.

\section{Jenis-jenis Kredit}

Kredit yang diberikan bank umum dan bank perkreditan rakyat untuk masyarakat terdiri dari berbagai jenis. Secara umum jenis-jenis kredit dapat dilihat dari berbagai segi antara lain sebagai berikut: Dilihat dari segi kegunaan, antara lain: a. Kredit investasi, biasanya digunakan untuk keperluan perluasan usaha atau membangun proyek/pabrik baru dan untuk keperluan rehabilitasi. Contoh kredit investasi misulnya untuk membangun pabrik atau membeli mesin-mesin. Pendek kata masa pemakaiannya untuk suatu periode yang relatif lebih lama. b. Kredit modal kerja, digunakan untuk keperluan meningkatkan produksi dalam operasionalnya. Sebagai contoh kredit modal kerja diberikan untuk membeli bahan baku, membayar gaji pegawai atau biaya-biaya lainnya yang berkaitan dengan proses produksi perusahaan.

Dilihat dari segi tujuan kredit, antara lain: a). Kredit produktif, Kredit yang digunakan untuk peningkatan usaha atau produksi atau investasi. Kredit ini diberikan untuk menghasilkan barang atau jasa. Sebagai contohnya kredit untuk membangun pabrik yang nantinya akan menghasilkan barang, kredit pertanian akan menghasilkan produk pertanian atau kredit pertambangan menghasilkan bahan tambang atau kredit industri lainnya. b). Kredit konsumtif, kredit yang digunakan untuk dikonsumsi secara pribadi. Tidak ada pertambahan barang dan jasa yang dihasilkan, karena memang untuk digunakan atau dipakai oleh seseorang atau badan usaha. Sebagai contoh kredit untuk perumahan, kredit mobil pribadi, kredit perabotan rumah tangga, dan kredit konsumtif lainnya. c). Kredit perdagangan, kredit yang digunakan untuk perdagangan, biasanya untuk membeli barang dagangan yang pembayarannya diharapkan dari hasil penjualan barang dagangan tersebut. Kredit ini sering diberikan kepada suplier atau agen-agen perdagangan yang akan membeli barang dalam jumlah besar. Contoh kredit ini misalnya kredit ekspor dan impor.

Dilihat dari segi jangka waktu, a. Kredit jangka pendek Merupakan kredit yang memiliki jangka waktu kurang dari 1 tahun atau paling lama 1 tahun dan biasanya digunakan untuk keperluan modal kerja. Contohnya untuk peternakan misalnya kredit peternakan ayam atau jika untuk pertanian misalnya tanaman padi atau palawija. b. Kredit jangka menengah jangka waktu kreditnya berkisar antara 1 tahun sampai dengan 3 tahun, biasanya untuk investasi. Sebagai contoh kredit untuk pertanian seperti jeruk, atau peternakan kambing. c. Kredit jangka panjang. Merupakan kredit yang masa pengembaliannya paling panjang. Kredit jangka panjang waktu pengembaliannya di atas 3 tahun atau 5 tahun. Biasanya kredit ini untuk investasi jangka panjang seperti perkebunan karet, kelapa sawit atau manu faktur dan untuk kredit konsumtif seperti kredit perumahan. 
Dilihat dari segi jaminan, a. Kredit dengan jaminan, kredit yang diberikan dengan suatu jaminan, jaminan tersebut dapat berbentuk barang berwujud atau tidak berwujud atau jaminan orang. Artinya setiap kredit yang dikeluarkan akan dilindungi senilai jaminan yang diberikan si calon debitur. b. Kredit tanpa jaminan, merupakan kredit yang diberikan tanpa jaminan barang atau orang tertentu. Kredit jenis ini diberikan dengan melihat prospek usaha dan karakter serta loyalitas atau nama baik si calon debitur selama ini.

Dilihat dari segi sektor usaha, a. Kredit pertanian, merupakan kredit yang dibiayai untuk sektor perkebunan atau pertanian rakyat. Sektor usaha pertanian dapat berupa jangka pendek atau jangka panjang. Kredit peternakan, dalam hal ini untuk jangka pendek misalnya peternakan ayam dan jangka panjang kambing atau sapi. b. Kredit industri, yaitu kredit untuk membiayai industry kecil, menengah atau besar. c. Kredit pertambangan, jenis usaha tambang yang dibiayainya biasanya dalam jangka panjang, seperti tambang emas, minyak atau timah. d. Kredit pendidikan, merupakan kredit yang diberikan untuk membangun sarana dan prasarana pendidikan atau dapat pula berupa kredit untuk para mahasiswa. e. Kredit profesi, diberikan kepada para professional seperti, dosen, dokter atau pengacara. f. Kredit perumahan, yaitu kredit untuk membiayai pembangunan atau pembelian perumahan. g. Sektor-sektor lainnya.

\section{Jaminan Kredit}

Seperti sudah dibahas di atas bahwa kredit dapat diberikan dengan jaminan atau tanpa jaminan. Kredit tanpa jaminan sangat membahaya- kan posisi bank, mengingat jika nasabah mengalami suatu kemacetan, maka akan sulit untuk menutupi kerugian terhadap kredit yang disalurkan. Sebaliknya dengan jaminan kredit relatif lebih aman mengingat setiap kredit macet akan dapat ditutupi oleh jaminan tersebut. (Suharto, 1998).

Adapun jaminan yang dapat dijadikan jaminan kredit oleh calon debitur adalah sebagai berikut:

Dengan jaminan, a). Jaminan benda berwujud, yaitu barang-barang yang dapat dijadikan jaminan seperti: Tanah, Bangunan, kendaraan bermotor, mesinmesin/peralatan, barang dagangan tanaman kebun/sawah dan lainnya. b). Jaminan benda tidak berwujud yaitu benda-benda yang merupakan surat-surat yang dijadikan jaminan seperti: sertifikat saham sertifikat obligasi, sertifikat tanah, sertifikat deposito, rekening tabungan yang dibekukan, rekening giro yang dibekukan promes, wesel, surat tagihan lainnya, c). Jaminan yang diberikan oleh seseorang dan apabila kredit tersebut macet, maka orang yang memberikan jaminan itulah yang menanggung risikonya.

Tanpa jaminan, kredit tanpa jaminan maksudnya adalah bahwa kredit yang diberikan bukan dengan jaminan barang tertentu. Biasanya diberikan untuk perusahaan yang memang benar-benar bonafid dan profesional sehingga kemungkinan kredit tersebut macet sangat kecil. Dapat pula kredit tanpa jaminan hanya dengan penilaian terhadap prospek usahanya atau dengan pertimbangan untuk pengusaha- pengusaha ekonomi lemah. (Suharto,1998).

\section{7. $\quad$ Prinsip-prinsip Pemberian Kredit}

Sebelum suatu fasilitas kredit diberikan. bank harus merasa yakin bahwa kredit yang diberikan benar-benar akan kembali. Keyakinan tersebut diperoleh 
dari hasil penilaian kredit sebelum kredit tersebut disalurkan. Penilaian kredit oleh bank dapat dilakukan dengan berbagai cara untuk mendapatkan keyakinan tentang nasabahnya, seperti melalui prosedur penilaian yang benar. Dalam melakukan penilaian kriteria-kriteria serta aspek penilaiannya tetap sama. Begitu pula dengan ukuran-ukuran yang ditetapkan sudah menjadi standar penilaian setiap bank. Biasanya kriteria penilaian yang hams dilakukan oleh bank untuk mendapatkan nasabah yang benar-benar menguntungkan dilakukan dengan analisis $5 \mathrm{C}$ dan $7 \mathrm{R}$, adapun penjelasan untuk analisis dengan $5 \mathrm{C}$ kredit adalah sebagai berikut: 1 . Character, suatu keyakinan bahwa, sifat atau watak dari orangorang yang akan diberikan kredit benar-benar dapat dipercaya, hal ini tercermin dari latar belakang si nasabah baik yang bersifat latar belakang pekerjaan maupun yang bersifat pribadi seperti: cara hidup atau gaya hiaup yang dianutnya, keadaan keluarga, hoby dan sosial standingnya. Ini semua merupakan ukuran "kemauan" membayar. 2. Capacity, untuk melihat nasabah dalam kemampuannya dalam bidang bisnis yang dihubungkan dengan pendidikannya, kemampuan bisnis juga diukur dengan kemampuannya dalam memahami tentang ketentuan-ketentuan pemerintah.

Begitu pula dengan kemampuannya dalam menjalankan usahanya selama ini. Pada akhirnya akan terlihat "kemampuannya" dalam mengembalikan kredit yang disalurkan. 3. Capital, untuk melihat penggunaan modal apakah efektif, dilihat laporan keuangan (neraca dan laporan mgi laba) dengan melakukan pengukuran seperti dari segi likuiditas, solvabilitas, rentabilitas, dan ukuran lainnya. Capital juga harus dilihat dari sumber mana saja modal yang ada sekarang ini. 4. Colleteral, merupakan jaminan yang diberikan calon nasabah baik yang bersifat fisik maupun non fisik. Jaminan hendaknya melebihi jumlah kredit yang diberikan. Jaminan juga harus diteliti keabsahannya sehingga jika terjadi suatu masalah, maka jaminan yang dititipkan akan dapat dipergunakan secepat mungkin. 5. Condition, dalam menilai kredit hendaknya juga dinilai kondisi ekonomi dan politik sekarang dan di masa yang akan datang sesuai sektor masingmasing, serta prospek usaha dari sector yang ia jalankan. Penilaian prospek bidang usaha yang dibiayai hendaknya benar-benar memiliki prospek yang baik sehingga kemungkinan kredit tersebut bermasalah relative kecil.

Kemudian penilaian kredit dengan metode analisis $7 \mathrm{P}$ adalah sebagai berikut: Personality, yaitu menilai nasabah dari segi kepribadiannya atau tingkah lakunya sehari-hari maupun masa lalunya. Personality juga mencakup sikap, emosi, tingkah laku, dan tindakan nasabah dalam menghadapi suatu masalah. Party, yaitu mengklasifikasikan nasabah ke dalam klasifikasi tertentu atau golongan-golongan tertentu berdasarkan modal, loyalitas serta karakternya. Sehingga nasabah dapat digolongkan ke golongan tertentu dan akan mendapatkan fasilitas yang berbeda dari bank. Perpose, yaitu untuk mengetahui tujuan nasabah dalam mengambil kredit, termasuk jenis kredit yang diinginkan nasabah. Tujuan pengambilan kredit dapat bermacammacam. Sebagai contoh apakah untuk modal kerja atau investasi, konsumtif atau produktif, dan lain sebagainya. Prospect, yaitu untuk menilai usaha nasabah di masa yang akan datang menguntungkan atau tidak, atau dengan kata lain mempunyai prospek atau sebaliknya. Hal ini penting mengingat jika suatu fasilitas kredit yang dibiayai tanpa mempunyai prospek, bukan hanya bank yang rugi, tetapi juga nasabah.

Payment, merupakan ukuran bagaimana cara nasabah mengembalikan kredit yang telah diambil atau dari sumber mana saja dana untuk pengembalian kredit. 
Semakin banyak sumber penghasilan debitor, akan semakin baik. Dengan demikian, jika salah satu usahanya merugiakan dapat ditutupi oleh sektor lainnya. Profitability, untuk menganalisis bagaimana kemampuan nasabah dalam mencari laba. Profitability diukur dari periode ke periode apakah akan tetap sama atau akan semakin meningkat, apalagi dengan tambahan kredit yang akan diperolehnya. Protection, tujuannya adalah bagaimana menjaga agar usaha dan jaminan mendapatkan perlindungan. Perlindungan dapat berupa jaminan barang atau orang atau jaminan asuransi.

\section{Aspek-aspek dalam Penilaian}

Karakteristik bank syarieah pada prinsip syariecah dalam pengelolaan harta menekankan pada keseimbangan antara kepentingan individu dan masyarakat. Harta sebaiknya dimanfaatkan untuk hal-hal produktif terutama kegiatan investasi yang merupakan landasan aktivitas ekonomi dalam masyarakat. Bank merupakan suatu lembaga yang menghubungkan masyarakat pemilik dana dengan pengusaha yang memerlukan dana, yang kegiatan usahanya berdasarkan prinsip syarie ah. Pengoprasionalan bank syariee ah berasaskan antara lain pada kemitraan, keadilan, transparan dan universal. Pasal 51 ayat (1) bank syarieeah dan Undang-undang Perbankan perlu menjaga tingkat kesehatannya dalam rangka memelihara kepercayaan masyarakat. (Aziz: 209, 2010).

Penilaian menggunakan $5 \mathrm{C}$ dan $7 \mathrm{P}$ maka penilaian suatu kredit layak atau tidak untuk diberikan dapat dilakukan dengan menilai seluruh aspek yang ada. Penilaian dengan seluruh aspek yang ada dikenal dengan nama studi kelayakan usaha. Penilaian dengan model ini biasanya digunakan untuk proyek-proyek yang bernilai besar dan berjangka waktu panjang.

Aspek-aspek yang dinilai antara lain sebagai berikut : Aspek Yuridis/Hukum, yang kita nilai dalam aspek ini adalah masalah legalitas badan usaha serta izinizin yang dimiliki perusahaan yang mengajukan kredit. Penilaian dimulai dengan akte pendirian perusahaan sehingga dapat diketahui siapa-siapa pemilik dan besarnya modal masing-masing pemilik. Kemudian juga diteliti keabsahannya adalah seperti: Surat Izin Usaha Industri (SIUI) untuk sektor industry, Surat Izin Usaha Perdagangan (SIUP) untuk sektor perdagangan, Tanda Daftar Pemsahaan (TDP), Nomor Pokok Wajib Pajak (NPWP), keabsahan surat-surat yang dijaminkan misalnya sertifikat tanah, serta hal-hal yang dianggap penting lainnya.

Aspek Pemasaran, dalam aspek ini yang kita nilai adalah permintaan terhadap produk yang dihasilkan sekarang ini dan di masa yang akan datang dapat terlihat prospek yang nyata, yang perlu diteliti dalam aspek ini adalah: Pemasaran produknya minimal tiga bulan yang lalu atau tiga tahun yang lalu, rencana penjualan dan produksi minimal tiga bulan atau tiga tahun yang akan datang, peta kekuatan pesaing yang ada, prospek produk secara keseluruhan.

Aspek Keuangan, aspek yang dinilai adalah sumber-sumber dana yang dimiliki untuk membiayai usahanya dan bagaimana penggunaan dana tersebut, hendaknya dibuatkan cash flow dari pada keuangan perusahaan. Penilaian bank dari segi aspek keuangan biasanya dengan suatu kriteria kelayakan investasi yang mencakup antara lain: Rasio-rasio keuangan, payback period, Net Present Value (NPV), Profitability Indek (PI), Internal Rate of Return (IRR), dan Break Even Point (BEP). 
Aspek Teknis/Operasi, aspek ini membahas masalah yang berkaitan dengan produksi sepeiti kapasitas mesin yang digunakan, masalah lokasi, lay out ruangan, dan mesin-mesin termasuk jenis mesin yang digunakan. Aspek Manajemen, untuk menilai struktur organisasi perusahaan, sumber daya manusia yang dimiliki serta latar belakang pengalaman sumber daya manusianya. Pengalaman perusahaan dal am mengelola berbagai proyek yang ada dan pertimbangan lainnya.

Aspek Sosial Ekonomi, menganalisis dampaknya terhadap perekonomian dan masyarakat umum seperti: 1. Meningkatkan ekspor barang, mengurangi pengangguran, meningkatkan pendapatan masyarakat, tersedianya sarana dan prasarana, membuka isolasi daerah tertentu. Aspek Amdal, menyangkut analisis terhadap lingkungan baik darat, air, atau udara jika proyek atau usaha tersebut dijalankan. Analisis ini dilakukan secara mendalam apakah apabila kredit tersebut disalurkan, maka proyek yang dibiayai akan mengalami pencemaran lingkungan di sekitamya. Pencemaran yang sering terjadi antara lain terhadap: tanah/darat menjadi gersang, air menjadi limbah berbau busuk, berubah warna atau rasa, udara mengakibatkan polusi, berdebu, bising dan panas.

\section{Prosedur dalam Pemberian Kredit}

Prosedur pemberian dan penilaian kredit oleh dunia perbankan secara umum antarbank yang satu dengan bank yang lain tidak jauh berbeda. Yang menjadi perbedaan mungkin hanya terletak dari prosedur dan persyaratan yang ditetapkannya dengan pertimbangan masing-masing. Prosedur pemberian kredit secara umum dapat dibedakan antara pinjaman perseorangan dengan pinjaman oleh suatu badan hukum, kemudian dapat pula ditinjau badan hukum sebagai berikut:

Pengajuan berkas-berkas, dalam hal ini pemohon kredit mengajukan permohonan yang dituangkan dalam suatu proposal. Kemudian dilampiri dengan berkas-berkas lainnya yang dibutuhkan. Pengajuan proposal kredit hendaknya yang berisi antara lain sebagai berikut: Latar belakang perusahaan seperti riwayat hidup singkat perusahaan, jenis bidang usaha, identitas perusahaan, nama pengurus berikut pengetahuan dan pendidikannya, perkembangan perusahaan serta relasinya dengan pihak-pihak pemerintah dan swasta.

Maksud dan tujuan, apakah untuk memperbesar omset penjualan atau meningkatkan kapasitas produksi atau mendirikan pabrik baru (perluasan) serta tujuan lainnya: Besarnya kredit dan jangka waktu, dalam hal ini pemohon menentukan besarnya jumlah kredit yang ingin diperoleh dan jangka waktu kreditnya. Penilaian kelayakan besamya kredit dan jangka waktunya dapat kita lihat dari cash flow serta laporan keuangan (neraca dan laporan rugi laba) tiga tahun terakhir. jika dari hasil analisis tidak sesuai dengan permohonan, maka pihak bank tetap berpedoman terhadap hasil analisis mereka dalam memutuskan jumlah kredit dan jangka waktu kredit yang layak diberikan kepada si pemohon.

Cara pemohon mengembalikan kredit, dijelaskan secara rinci cara-cara nasabah dalam mengembalikan kreditnya apakah dari hasil penjualan atau cara lainnya, jaminan kredit, hal ini merupakan jaminan untuk menutupi segala risiko terhadap kemungkinan macetnya suatu kredit bank maka pihak bank haruslah teliti jangan sampai terjadi sengketa, palsu, dan sebagainya, bsiasanya jaminan diikat dengan suatu asuransi tertentu. 
Proposal dilampiri dengan berkas-berkas yang telah dipersyaratkan seperti: 1. Akte notaris, dipergunakan untuk perusahaan yang berbentuk PT (Perseroan Terbatas) atau yayasan, 2. TDP (Tanda Daftar Perusahaan), Merupakan tanda daftar perusahaan yang dikeluarkan oleh Departemen Perindustrian dan Perdagangan dan biasanya berlaku lima tahun, jika habis dapat diperpanjang kembali. 3. NPWP (Nomor Pokok Wajib Pajak), Nomor pokok wajib pajak, di mana sekarang ini setiap pemberian kredit terns dipantau oleh Bank Indonesia adalah NPWP. 4. Neraca dan laporan rugi laba tiga tahun terakhir, 5. Bukti diri dari pimpinan perusahaan, 6 . Foto kopi sertifikat jaminan.

Penilaian, yang dapat kita lakukan untuk sementara adalah dari neraca dan laporan rugi laba yang ada dengan menggunakan rasio-rasio sebagai berikut: 1 . current ratio, 2. acid test ratio, 3. Inventory turn over, 4. Sales to receivable ratio, 5. Profit margin ratio, 6. Return on net worth, 6. working capital.

Penyelidikan berkas pinjaman, tujuannya adalah untuk mengetahui apakah berkas yang diajukan sudah lengkap sesuai persyaratan dan sudah benar. Jika menurut pihak perbankan belum lengkap atau cukup, maka nasabah diminta untuk segera melengkapinya dan apabila sampai batas tertentu nasabah tidak sanggup melengkapi kekurangan tersebut, maka sebaiknya permohonan kredit dibatalkan saja.

Wawancara I, merupakan penyidikan kepada calon peminjam dengan langsung berhadapan dengan calon peminjam, untuk meyakinkan apakah berkasberkas tersebut sesuai dan lengkap seperti yang bank inginkan. Wawancara ini juga untuk mengetahui keinginan dan kebutuhan nasabah yang sebenarnya. Hendaknya dalam wawancara ini dibuat serilek mungkin sehingga diharapkan hasil wawancara akan sesuai dengan tujuan yang diharapkan.

On the Spot, merupakan kegiatan pemeriksaan ke lapangan dengan meninjau berbagai objek yang akan dijadikan usaha atau jaminan. Kemudian hasil on the spot dicocokkan dengan hasil wawancara I. Pada saat hendak melakukan on the spot hendaknya jangan diberitahu kepada nasabah. Sehingga apa yang kita lihat di lapangan sesuai dengan kondisi yang sebenarnya. Wawancara II merupakan kegiatan perbaikan berkas, jika mungkin ada kekurangan-kekurangan pada saat setelah dilakukan on the spot di lapangan. Catatan yang ada pada permohonan dan pada saat wawancara I dicocokkan dengan pada saat on the spot apakah ada kesesuaian dan mengandung suatu kebenaran.

Keputusan kredit, keputusan kredit dalam hal ini adalah menenttikan apakah kredit akan diberikan atau ditolak, jika diterima, maka dipersiapkan administrasinya, biasanya keputusan kredit yang akan mencakup: jumlah uang yang diterima, jangka waktu kredit, dan biaya-biaya yang harus dibayar. Keputusan kredit biasanya merupakan keputusan team. Begitu pula bagi kredit yang ditolak, maka hendaknya dikirim surat penolakan sesuai dengan alasannya masing-masing.

Penandatanganan akad kredit/perjanjian lainnya, kegiatan ini merupakan kelanjutan dari diputuskannya kredit, maka sebelum kredit dicairkan maka terlebih dulu calon nasabah menandatangani akad kredit, mengikat jaminan dengan hipotek dan surat perjanjian atau pernyataan yang dianggap perlu. Penanda tanganan dilaksanakan: 1. Antara bank dengan debitur secara langsung atau, dengan melalui notaris. 
Realisasi kredit, realisasi kredit diberikan setelah penandatanganan suratsurat yang diperlukan dengan membuka rekening giro atau tabungan di bank yang bersangkutan. Penyaluran/penarikan dana, adalah pencairan atau pengambilan uang dari rekening sebagai realisasi dari pemberian kredit dan dapat diambil sesuai ketentuan dan tujuan kredit yaitu:1. Mencari keuntungan Tujuan utama dari pemberian kredit hasilnya berupa keuntungan. 2. Membantu usaha nasabah, 3. Membantu pemerintah bagi pemerintah. (Ibrahim, 2004: 93)

\section{Simpulan}

Kegiatan Pengabdian ini dilakukan dalam bentuk sosialisasi. Sosialisasi ini dilakukan selama 2 hari yaitu pada Hari/ Tanggal: Kamis-Jum'at/ 9-10 Januari 2020. Adapun peserta sosialisasi ini adalah siswa-siswi SMA Tri Dharma Palembang. Jumlah peserta sosialisasi ini sebanyak 25 (dua puluh lima) siswa. Dari hasil kegiatan sosialisasi ini dapat diketahui bahwa persentasi peserta sebanyak 25 orang memahami materi yang diberikan sebanyak :

\begin{tabular}{|c|c|c|}
\hline Materi & $\begin{array}{l}\text { (\%) Pemahaman } \\
\text { Sisiwa/i }\end{array}$ & Ket \\
\hline $\begin{array}{l}\text { Materi Hari Pertama: } \\
\text { 1. Pengertian Pengalokasian Dana }\end{array}$ & $85 \%$ & \\
\hline 2. Pengertian Kredit dan Pembiayaan & $80 \%$ & \\
\hline $\begin{array}{l}\text { 3. Penyaluran Dana Pembiayaann Kepada } \\
\text { Masyarakat }\end{array}$ & $75 \%$ & \\
\hline 4. Unsur-unsur Kredit. & $82 \%$ & \\
\hline $\begin{array}{l}\text { Materi Hari Ke Dua: } \\
\text { 1. Tujuan dan Fungsi Kredit }\end{array}$ & $86 \%$ & \\
\hline 2. Jenis-jenis Kredit dan Jaminan Kredit. & $78 \%$ & \\
\hline $\begin{array}{l}\text { 3. Prinsip-prinsip Pemberian Kredit, Aspek- } \\
\text { aspek dalam Penilaian. }\end{array}$ & $80 \%$ & \\
\hline 4. Prosedur dalam Pemberian Kredit. & $83 \%$ & \\
\hline
\end{tabular}




\section{Daftar Pustaka}

Aziz, Abdul. 2010. Manajemen Investasi Syari"ah. Bandung: Alfabeta.

Djumhana, Muhammad. 2003. Ekonomi Koperasi,Fakultas Ekonomi. UI.

Fuady, Munir. 2002. Manajemen Perbankan. RajaGrafindo Persada. Jakata.

Ibrahim, Johannes. 2004. Perkoperasian Sejarah. Teori dan Praktek. Ghalia Indonesia.

Kasmir, 2014. Analisis Laporan Keuangan, Edisi Pertama, Cetakan Ketujuh. Jakarta: Rajagrafindo Persada.

Karim, Adiwarman. 2006. Bank Islam Analisis Fiqh dan Keuangan. Jakarta: Raja Grafindo Persada.

Muhammad. 2000. Sistem dan Prosedur Operasional Bank Syariah, Yogyakarta: UII Press.

Nasution, Anwar. 1990. Tinjauan Ekonomi atas Dampak Paket Diregulasi tahun 1988 pada Sistem Keuangan Indonesia PAU-EKONOMI-UI. Jakarta: Gramedia.

Siamat, Dahlan. 2001. Ilmu pengantar koperasi. Jakarta.

Suharto, Pandu. 1998. Sejarah Pendirian Bank Perkreditan Rakyat. Jakarta: LPPI.

\section{Internet:}

ttps://www.jogloabang.com/pustaka/uu-10-1998-perubahan-uu-7-1992-perbankan 